\title{
PEMANFATAAN MEDIA SOSIAL FACEBOOK SEBAGAI STRATEGI KOMUNIKASI POLITIK
}

\author{
Suratno', Irwansyah ${ }^{2}$, Niken F. Ernungtyas ${ }^{3}$, Guntur F. Prisanto ${ }^{4}$, Safira Hasna ${ }^{5}$ \\ 1,3, 4 Sekolah Tinggi Ilmu Komunikasi Inter Studi \\ 2 Universitas Indonesia
}

\begin{abstract}
Political candidates are actively using Facebook's social media as a political communication strategy, for which there is social interaction and interactive dialogues between the candidates and the public in virtual space, where this is needed to influence public involvement in achieving their political missions. Therefore, the objective of this study is to describe the influence of the use of social media Facebook as a political communication strategy on the electability, effectiveness, and popularity of the candidates of the DPR RI members in 2019 legislative elections. The research used theories and concepts of uses and gratification theory, political communication and the use of social media in political communication, using quantitative research methods and surveys of 30 Facebook user respondents and voters in the 2019 legislative elections. The results showed there was an impact of Facebook utilization on the electability by $16 \%$, on effectiveness by $39.7 \%$, and on the popularity of prospective members of the DPR RI in the 2019 legislative elections by $17.3 \%$. Users can actively collect information and opinions using this site as a place of communication between themselves with the politicians or with fellow supporters. However, the use of Facebook is not the only effective political communication strategy, traditional media such as television, radio, billboards, stickers are still effective to reach the public who do not always use social media.
\end{abstract}

\author{
Keywords \\ Facebook, Political \\ Communication, Social Media, \\ Electability, Effectiveness, \\ Popularity.
}

Correspondence Contact anokusairi@gmail.com

\section{PENDAHULUAN}

Penggunaan media sosial saat ini bukan hanya sekedar untuk berinteraksi dan mencari informasi secara umum, tetapi juga telah menjadi tools yang dimanfaatkan bagi politisi, partai politik, kandidat politik untuk berpartisipasi secara aktif dalam komunikasi politik terutama selama kampanye pemilihan untuk mendapatkan banyak suara dan mencapai kemenangan. Secara umum, saluran komunikasi pemasaran seperti koran, iklan, radio, baliho, mulai tergantikan oleh internet dan layanan media sosial sebagai saluran utama dari perusahaan ke pelanggan mereka, perubahan ini juga diadopsi oleh politisi dalam kampanye pemilihan umum (Hong \& Nadler, 2012). Terlebih lagi, media tradisional juga telah mengakui pentingnya media sosial untuk penggunaan politik. Wislow (2012) meneliti bagaimana stasiun televisi ternama menyiarkan siaran utama ke berbagai platform media sosial selama musim pemilihan. Contohnya, CNN yang bekerja sama dengan Facebook dan memberikan data Pemilu serta menganalisis aktivitas publik dalam partisipasi politik di berbagai media sosial. NBC bekerja sama dengan Cromson Hexagon dan menganalisis media sosial dan aktivitas politik di media sosial, dan masih banyak lagi (Borah, 2016).

Persaingan dalam pemilihan anggota legislatif membuat kandidat politik harus memanfaatkan tools dalam berkomunikasi kepada publiknya dengan baik. Media sosial disini dapat memfasilitasi proses promosi ide-ide kandidat, penyebaran pesan politik, sehingga akan mendapatkan pendukung yang dapat membantu mereka dalam proses pemilihan umum 
(pemilu). Salah satu media sosial yang dapat digunakan dalam komunikasi politik adalah Facebook. Facebook merupakan salah satu media sosial yang mendominasi dunia. Tahun 2018, pengguna Facebook aktif mencapai 2,17 miliar. Indonesia sendiri memiliki jumlah pengguna Facebook tertinggi keempat di dunia. Ini menjadikan Indonesia menjadi negara di Asia Tenggara dengan jumlah pengguna Facebook terbanyak (The Jakarta Post, 2018). Oleh karena itu, Facebook dapat menjadi media sosial yang diadopsi oleh para politisi untuk menyebarkan ide, mempengaruhi opini individu, mendorong publik untuk mengadopsi ide mereka, dan memilih mereka dalam pemilihan (Yousif \& ALsamydai, 2012).

Untuk mencapai tujuan politiknya yaitu mendapatkan suara saat pemilihan berlangsung, seorang kandidat politik terlebih dahulu harus memiliki elektabilitas dan popularitas yang tinggi serta sadar akan efektivitas kampanye yang dilakukan. Ketiga indikator tersebut dapat dicapai dengan strategi komunikasi politik yang baik, dimana semakin dekat dengan publik, maka semakin besar kesempatan kandidat untuk dikenal para pemilih (Irawan, 2014). Apapun yang dilakukan oleh kandidat dapat ditunjukkan melalui media sosial khususnya Facebook. Menurut pihak Facebook, selama Pemilu 2019 setiap harinya banyak orang menggunakan Facebook untuk berdiskusi tentang percakapan politis (Dewi, 2019), ini termasuk calon legislatif anggota DPR RI dimana mereka menggunakan Facebook untuk mensosialisasikan visi misi,gagasan serta tentang dirinya ke publik.

Terdapat beberapa penelitian terdahulu terkait dengan penelitan ini. Pertama, Spierings \& Jacobs (2019) dalam penelitiannya berjudul Getting Personal? The Impact of Social Media on Preferential Voting menemukan bahwa politisi di Belanda sering menggunakan media sosial Twitter saat kampanye pemilihan. Hasilnya, kandidat yang aktif di Twitter dan memiliki followers cenderung lebih banyak mendapatkan jumlah suara dibandingkan mereka yang tidak aktif di media sosial. Pesan yang disampaikan dan interaktivitas kepada pengguna dapat membuat kandidat terasa lebih dekat dengan publik (Spierings \& Jacobs, 2014).

Penelitian kedua oleh Lin (2017) mengenai How Political Candidates' Use of Facebook Relates To The Election Outcomes di Taiwan menemukan bahwa politisi yang menggunakan media sosial memiliki kesempatan untuk mendapatkan banyak suara dan memenangkan pemilihan. Pemilihan jenis akun Facebook juga mempegaruhi hasil pemilu dimana kandidat dengan "Facebook Page" cenderung memiliki suara yang lebih banyak dibandingkan jenis akun Facebook lainnya (personal). Lewat Facebook, politisi dapat mendiskusikan pandangan politiknya kepada pengikut dan masyarakat umum lainnya, dimana mereka dapat bertukar pendapat lewat kolom komentar (Lin, 2017).

Ketiga, Yousif dan ALsamydai (2012) dengan penelitian berjudul The Impact of the Political Promotion via Facebook on Individual Political Orientations meneliti tentang bagaimana politisi mempromosikan dirinya lewat pesan di media sosial Facebook sehingga akan mempengaruhi pilihan seseorang saat pemilu. Hasilnya, Facebook dapat menjadi media untuk menyebarkan pesan politik. Dengan mengaitkan pesan kepada suatu event politik, seseorang dapat menjadi tertarik dengan keadaan politik saat ini melalui suatu pesan yang disebarkan lewat Facebook (Yousif \& ALsamydai, 2012). Ketiga penelitian terdahulu memiliki kesamaan dengan penelitian ini karena media sosial yang digunakan untuk komunikasi politik adalah Facebook, namun konteks penelitian ini berada di Indonesia dan memiliki tiga variabel dependen yang berbeda dari penelitian sebelumnya yaitu elektabilitas, efektivitas, dan popularitas calon anggota legislatif (DPR RI) pada Pemilu 2019.

Penelitian ini memiliki tiga rumusan masalah, yaitu 1) Apakah terdapat pengaruh penggunaan Facebook terhadap elektabilitas calon anggota DPR RI pada pemilu legislatif 2019? 2) Apakah terdapat pengaruh penggunaan Facebook terhadap efektivitas kampanye 
calon anggota DPR RI pada pemilu legislatif 2019?, dan 3) Apakah terdapat pengaruh penggunaan Facebook terhadap popularitas calon anggota DPR RI pada pemilu legislatif 2019? Adapun tujuan penelitian ini adalah untuk mendeskripsikan bagaimana pengaruh pemanfaatan media sosial Facebook sebagai strategi komunikasi politik terhadap elektabilitas, efektivitas, dan popularitas calon anggota DPR RI pada pemilu legislatif 2019.

\section{KAJIAN TEORITIS}

\section{Teori Uses and Gratification}

Sebagai salah satu teori komunikasi yang lama dan berkembang, uses and gratification menjelaskan motivasi untuk memperoleh informasi melalui media. Teori ini mengatakan bahwa khalayak secara aktif menggunakan (uses) media tertentu untuk menghasilkan kepuasan (gratification) tertentu. Khalayak dianggap aktif karena mampu mempelajari dan mengevaluasi berbagai jenis media untuk mencapai tujuan komunikasi (Griffin, 2012).

Teori U\&G memiliki lima asumsi dasar. Pertama, adanya khalayak aktif. Kedua, penggunaan media berorientasi dengan adanya kebutuhan dan motif khalayak. Ketiga, adanya kepuasan yang dihasilkan. Keempat, konsumsi media memenuhi kebutuhan khalayak, dari pelarian fantasi sampai pendidikan dan mencari informasi. Kelima, seseorang memiliki kesadaran diri yang cukup untuk mengetahui dan mengartikulasikan alasan mereka untuk menggunakan media tertentu, berasal dari konten media, eksposur, dan konteks di mana eksposur terjadi (Lariscy, Tinkham, \& Sweetser, 2011). Penelitian terdahulu menunjukkan adanya dua jenis gratifikasi yang berbeda, yaitu content gratification dan process gratification. Dalam konten, menerima pesan tertentu lebih penting, sementara pada proses gratifikasi, berpartisipasi dalam "proses penggunaan" media memiliki nilai yang jauh lebih tinggi (Mehrad \& Tajer, 2016).

Jika dikaitkan dengan politik, awalnya teori U\&G digunakan untuk melihat gratifikasi dari menonton siaran politik, seperti untuk melihat alasan politik, penguatan atau pedoman pemilihan dalam politik, pengawasan, serta kegembiraan melihat pesta politik (Lariscy et al., 2011). Dengan adanya media online, peneliti komunikasi politik menyelidiki adanya U\&G dari berbagai bentuk informasi politik secara online, seperti website, blog, forum, e-bulletin, dan media sosial. Penggunaan internet khususnya media sosial pada politik dapat memberikan kepuasan guna mendapatkan informasi dari calon anggota legislatif yang akan di pilih khalayak dengan melihat pada elektabilitas, efektivitas, seta popularitas calon anggota legislatif.

\section{Komunikasi Politik}

Komunikasi politik merupakan segala bentuk komunikasi yang diperlukan untuk membangun dan memelihara hubungan serta mengkoordinasikan kegiatan yang diperlukan oleh calon kandidat terpilih (politisi), relawan, donor, aktivis, serta pendukungnya. Jika kampanye politik dilakukan untuk membangun aliansi antara kelompok-kelompok dengan minat dan tujuan yang sama, maka komunikasi diperlukan untuk membangun dan memelihara hubungan untuk menjangkau dan membantu meyakinkan publik untuk secara aktif mendukung kampanye politik seseorang (Strömbäck \& Kiousis, 2014). Sebagaimana layaknya proses komunikasi, komunikasi politik juga harus memiliki unsur-unsur komunikator, pesan, channel, penerima dan efeknya. Setiap elemen saling mempengaruhi keberhasilan dari suatu kegiatan komunikasi politik, jika salah satu elemen-elemen ini tidak berfungsi dengan baik, maka dapat dipastikan tujuan suatu aktivitas komunikasi politik tidak tercapai. Komunikasi politik memiliki lima fungsi dasar (McNair, 2003): 
a. Memberikan informasi kepada publik tentang apa yang terjadi di sekitarnya

b. Mendidik publik terhadap arti dan signifikansi fakta yang ada

c. Menyediakan platform untuk mengakomodasi isu-isu politik sehingga dapat menjadi wacana dalam membentuk opini publik dan mengembalikan hasil opini kepada masyarakat

d. Membuat publikasi yang ditujukan kepada pemerintah dan lembaga-lembaga politik

e. Dalam masyarakat yang demokratis, komunikasi politik dapat berfungsi sebagai media penyalur advokasi yang dapat membantu kebijakan dan program lembaga politik.

Komunikasi politik saat ini harus mampu memanfaatkan media sosial sebagai medium yang melengkapi media tradisional untuk dapat meningkatkan pengetahuan publik terhadap kandidat politik dalam pemilu legislatif.

\section{Penggunaan Media Sosial dalam Komunikasi Politik}

Media sosial adalah media online yang memungkinkan penggunanya untuk dengan mudah berpartisipasi, berbagi, dan membuat konten. Media sosial juga dapat didefinisikan sebagai media online yang mendukung interaksi sosial dengan menggunakan teknologi berbasis web yang mengubah komunikasi menjadi dialog interaktif (Suprajang, Nirwanto, \& Firdianjah, 2017). Dengan tumbuhnya penggunaan media sosial khususnya Twitter dan Facebook, media sosial saat ini digunakan baik oleh masyarakat maupun institusi politik (politisi, partai politik, political foundation, dll). Dari perspektif lembaga politik, penting untuk berpartisipasi aktif dalam komunikasi politik menggunakan media sosial, terutama selama kampanye pemilihan. Karena media sosial dapat menjadi channel untuk merepresentasikan informasi yang ideal, mengukur opini publik, serta mendapatkan dukungan dari publik kepada kandidat politiknya (Zeng, Chen, Lusch, \& Li, 2010). Penelitian terdahulu menunjukkan bahwa politisi di era demokrasi yang modern ini dengan semangat mengadopsi media sosial untuk melibatkan publik, berdialog dengan warganya sehingga memunculkan diskusi politik yang 'hidup' (Hong \& Nadler, 2011). Selain itu, dengan adanya media sosial memungkinkan masyarakat untuk mendapat informasi dan pengaruh pilihan politik, dari mulai sikap, kepercayaan, dan perilaku mereka terhadap kandidat politik tertentu (Victor, Ikechukwu, Gerald, \& Chinedum, 2017).

Media sosial seperti Facebook telah menjadi ruang pertemuan online oleh banyak orang untuk berinteraksi dan mengekspresikan diri. Media sosial menawarkan cara untuk tetap berhubungan seperti pada dunia offline, adanya grup sosial dan profesional. Media sosial juga memungkinkan orang-orang yang jarang berkomunikasi untuk tetap terhubung. Politisi dapat berinteraksi dengan pendukungnya meskipun memiliki jadwal yang padat, dan masyarakat dapat menunjukkan dukungannya lewat fitur komentar di media sosial (Victor et al., 2017).

Media sosial digunakan dalam komunikasi politik khususnya saat pemilu legislatif 2019 bertujuan untuk dapat menaikkan peluang kemenangan untuk terpilih, dengan mencapai elektabilitas yang tinggi, efektivitas kampanye yang dilakukan, serta popularitas kandidat calon legislatif.

\section{METODOLOGI}

Penelitian menggunakan metode kuantitatif, dimana dalam penelitian ini menjelaskan fenomena yaitu bagaimana strategi komunikasi politik menggunakan media sosial Facebook dapat mempengaruhi variabel dependen elektabilitas, efektivitas, dan popularitas dengan mengumpulkan data numerik yang dianalisis menggunakan metode berbasis matematis 
(khususnya statistik) (Muijs, 2004). Pengukuran dalam metode kuantitatif digunakan untuk menggambarkan perbedaan antara orang-orang dalam karakteristik yang bersangkutan, pengukuran juga memberi tolak ukur yang konsisten untuk mengukur perbedaan satu variabel dengan variabel lainnya, serta pengukuran memberikan dasar untuk perkiraan yang lebih tepat dari tingkat hubungan satu konsep dengan konsep lainnya (misalnya melalui analisis korelasi) (Bryman, 2012). Penelitian ini menggunakan survey dengan populasi 1) pria dan wanita, 2) pengguna media sosial Facebook, dan 3) pemilih pada Pemilu legislatif 2019. Pengambilan sampel dilakukan dengan teknik simple random sampling, dimana seluruh populasi memiliki probabilitas yang sama untuk dipilih menjadi sampel (Taherdoost, 2018). Sampel pada penelitian ini adalah 30 orang pengguna Facebook dan pemilih pada pemilu legislatif 2019.

Berikut model analisis dalam penelitian ini.

Gambar 1. Model Penelitian

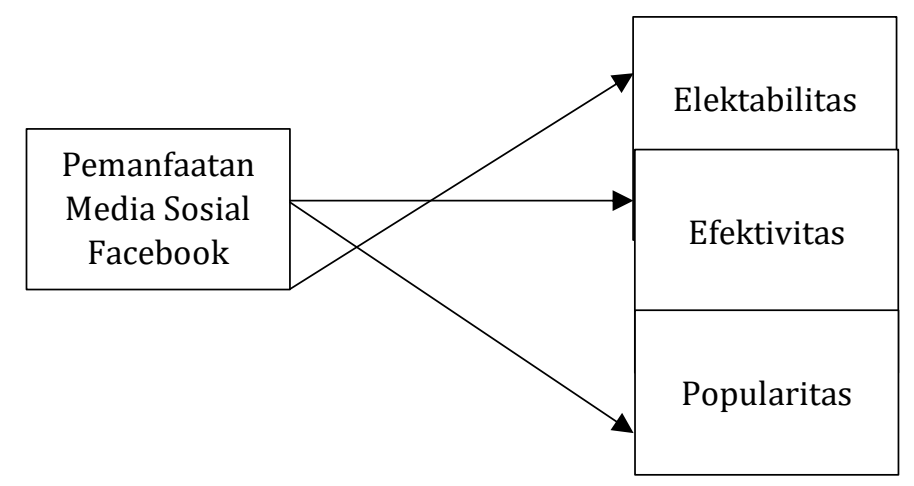

Adapun variabel pemanfaatan media sosial Facebook bertindak sebagai variabel independen, dan variabel elektabilitas, efektivitas, dan popularitas menjadi variabel dependen.

Pada penelitian ini, terdapat tiga hipotesis yang akan diuji, yaitu:

H1 : Terdapat pengaruh pemanfaatan media sosial Facebook terhadap elektabilitas calon anggota legislatif DPR RI pada pemilu legislatif 2019.

H2 : Terdapat pengaruh pemanfaatan media sosial Facebook terhadap efektivitas kampanye politik calon anggota legislatif DPR RI pada pemilu legislatif 2019.

H3 : Terdapat pengaruh pemanfaatan media sosial Facebook terhadap popularitas calon anggota legislatif DPR RI pada pemilu legislatif 2019.

\section{HASIL DAN PEMBAHASAN}

Penelitian mengumpulkan responden $(\mathrm{N}=30)$ yang terdiri dari perempuan $(53,3 \%)$ dan lakilaki $(46,7 \%)$. Seluruh responden diminta mengisi kuesioner yang terdiri dari empat variabel yaitu (1) penggunaan media sosial Facebook, (2) elektabilitas, (3) efektivitas dan (4) popularitas. Masing-masing variabel diukur dengan skala likert lima poin. Sebelum melakukan uji hipotesis, peneliti terlebih dahulu menguji validitas dan reliabilitas untuk memastikan indikator dalam penelitian valid dan reliabel. 
Tabel 1. Uji Validitas dan reliabilitas

\begin{tabular}{l|l|l|l} 
Variabel & KMO & $\boldsymbol{\alpha}$ & Keterangan \\
\hline $\begin{array}{l}\text { Penggunaan Media Sosial } \\
\text { Facebook }\end{array}$ & 0.568 & 0.756 & Valid dan reliabel \\
\hline Elektabilitas & 0.650 & 0.765 & Valid dan reliabel \\
\hline Efektivitas & 0.664 & 0.831 & Valid dan reliabel \\
\hline Popularitas & 0.708 & 0.768 & Valid dan reliabel \\
\hline
\end{tabular}

\section{Sumber Data: olahan SPSS}

Hasil uji validitas dan reliabilitas indikator pertanyaan menujukkan seluruh variabel memiliki nilai diatas 0,5 sehingga semua variabel dianggap valid. Kemudian berdasarkan uji reliabilitas, seluruh variabel menunjukkan nilai alpha cronbach diatas 0,7 yang artinya reliabel.

Selanjutnya, peneliti menggunakan uji regresi linear untuk mengetahui seberapa besar pengaruh penggunaan Facebook terhadap elektabilitas, efektivitas, dan popularitas.

Tabel 2. Nilai R Square

\begin{tabular}{|c|c|c|}
\hline Variabel & R Square & Keterangan \\
\hline $\begin{array}{lll}\text { Penggunaan } & \text { Media } & \text { Sosial } \\
\text { Facebook } & & \\
\end{array}$ & - & 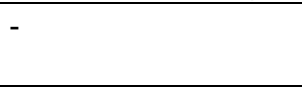 \\
\hline Elektabilitas & 0,160 & Sangat rendah \\
\hline Efektivitas & 0,397 & Rendah \\
\hline Popularitas & 0,173 & Sangat rendah \\
\hline
\end{tabular}

Dari tabel diatas, diketahui variabel penggunaan Facebook mempengaruhi variabel elektabilitas dengan nilai $\mathrm{R}$ square sebesar 0,160 atau $16 \%$ yang artinya besar pengaruh sangat rendah, dimana sisa nilai tersebut yaitu $84 \%$ merupakan faktor lain yang mempengaruhi elektabilitas calon anggota legislatif DPR RI pada Pemilu 2019. Sedangkan pengunaan Facebook mempengaruhi efektivitas dengan rendah yaitu sebesar 0,397 atau $39,7 \%$, sisanya $60,3 \%$ dipengaruhi oleh faktor lain. Dan terakhir, penggunaan media sosial Facebook juga mempengaruhi variabel popularitas sangat rendah yaitu sebesar 0,173 atau $17,3 \%$, sisanya $82,7 \%$ dipengaruhi oleh faktor lainnya.

Setelah melihat nilai R Square, peneliti menguji masing-masing hipotesis, dimana hipotesis akan diterima jika Sig $<0,05$.

Tabel 3. Uji Hipotesis Antar Variabel

\begin{tabular}{l|l|l} 
Variabel & Sig & Keterangan \\
\hline $\begin{array}{l}\text { H1: Penggunaan Media Sosial Facebook -> } \\
\text { Elektabilitas }\end{array}$ & 0,029 & Terbukti \\
\hline $\begin{array}{l}\text { H2: Penggunaan Media Sosial Facebook -> } \\
\text { Efektivitas }\end{array}$ & 0,000 & Terbukti \\
\hline $\begin{array}{l}\text { H3: Penggunaan Media Sosial Facebook -> } \\
\text { Popularitas }\end{array}$ & 0,022 & Terbukti \\
\hline
\end{tabular}


Dari tabel di atas, dapat diketahui H1 diterima karena nilai signya yaitu 0,029 $<0,05$, yang artinya penggunaan media sosial Facebook berpengaruh secara signifikan terhadap elektablitas caleg DPR RI pada pemilu legislatif 2019. Untuk meningkatkan elektabilitas maka objek yang dinilai elektabilitasnya kerap menggunakan media sosial untuk mempromosikan program serta prestasi yang mereka miliki sehingga daya pilih mereka akan meningkat. Dengan dialog dua arah lewat kolom komentar, atau fitur like yang ada pada Facebook, membuat publik merasa calon kandidatnya layak untuk dipilih. Hal ini juga sejalan dengan studi yang dilakukan Raenaly, Erviatno, Bandiyah (2017) dimana penelitian menunjukkan bahwa kampanye di media sosial dapat mempengaruhi elektabilitas pasangan calon gubernur DKI Jakarta pada Pilkada 2017.

Media sosial Facebook menghasilkan dan mempertahankan minat seseorang kepada calon kandidat dalam suatu kampanye. Pengguna mengumpulkan informasi, opini, menggunakan situs interaktif ini sebagai tempat komunikasi secara terus menerus antara pemilih dan politisi, dimana informasi mengalir langsung dari calon anggota legislatif di halaman Facebook. Namun, penelitian menunjukkan pengaruh yang sangat rendah, artinya terdapat faktor lain yang mempengaruhi elektabilitas kandidat, dimana media sosial lain seperti Twitter dapat mempengaruhi elektabilitas, mengingat jelang Pemilu 2019 banyak hashtag terkait Pemilu 2019 menjadi trending topics di media sosial Twitter. Selain itu, afiliasi partai politik atau sejarah kandidat sebelumnya dapat menjadi faktor lain yang mempengaruhi elektabilitas.

Selanjutnya, H2 juga diterima karena nilai signya $0,000<0,05$, yang artinya penggunaan media sosial Facebook berpengaruh secara signifikan terhadap efektivitas kampanye politik. Facebook merupakan platform media sosial pertama kali yang dirancang sebagai schoolbased community, namun media sosial ini diperluas kepada publik dan sekarang mencapai 1 miliar pengguna di seluruh dunia. Facebook memungkinkan untuk pembuatan grup, undangan acara, pesan pribadi, serta fitur "wall" untuk publik yang dapat diatur untuk berbagi konten. Fitur-fitur ini memperluas ruang publik dan menjadi media promosi untuk keterlibatan politik. Penelitian-penelitian sebelumnya mengeksplorasi penggunaan Facebook biasanya memang digunakan untuk kampanye dan fokusnya untuk meningkatkan kesadaran politik (Borah, 2016). Dengan banyaknya pengguna media sosial yang bergabung dalam suatu percakapan di media sosial, menjadikan media sosial sebagai salah satu cara yang efektif bagi politisi untuk mencapai konstituennya. Namun, penggunaan Facebook bukan menjadi satusatunya media yang membuat kampanye politik menjadi efektif, bagaimanapun juga kampanye dengan media tradisional seperti TV, radio, baliho, stiker juga masih menjadi alat kampanye yang digunakan kandidat politik untuk menjangkau publik yang tidak selalu menggunakan media sosial sehari-harinya, hal ini dapat dilihat dari besar pengaruh yang rendah antar variabel penggunaan Facebook dengan efektivitas kampanye politik pada penelitian ini.

Terakhir, $\mathrm{H} 3$ dalam penelitian juga diterima dengan nilai sig $0,022<0,05$, artinya penggunaan media sosial Facebook berpengaruh secara signifikan terhadap popularitas calon anggota legislatif DPR RI pada Pemilu 2019. Pada Facebook page, kandidat dapat mengunggah video, foto, acara, pesan, pembaharuan status dan program politik yang mereka miliki sehingga mendapatkan pendukung baru atau mempertahankan pendukung yang ada sehingga popularitas kandidat semakin tinggi. Pendukung dapat memilih untuk menyukai posting sebagai bentuk pemberian dukungan, mengomentari untuk berinteraksi dengan kandidat atau pengikut lainnya serta berbagi posting kepada teman mereka, hal ini akan menambah popularitas dari kandidat politik ke publik (Lin, 2017). Oleh karena itu, calon anggota legislatif harus secara aktif meningkatkan jumlah pendukung dengan secara selektif memilih pesan yang ingin mereka unggah (Zhang \& Peng, 2015), karena dukungan online yang terlihat dari 
seorang individu untuk kandidat tersebut dapat menjadikan mereka memilih pada saat pemilihan legislatif berlangsung.

\section{PENUTUP}

Dari penelitian yang dilakukan, dapat disimpulkan bahwa terdapat pengaruh pemanfaatan media sosial Facebook terhadap elektabilitas, efektivitas, dan popularitas calon legislatif anggota DPR RI pada Pemilu legislatif 2019 dengan nilai Sig masing-masing variabel < 0,05. Pemanfaatan media sosial Facebook membuat calon kandidat dapat melakukan komunikasi untuk mempromosikan program serta prestasi yang ia miliki, selanjutnya publik dapat dengan mudah mengumpulkan informasi, opini, dan menganggap kandidat layak untuk dipilih pada pemilihan nanti, sehingga elektabilitas kandidat dapat naik. Penggunaan media sosial Facebook juga berpengaruh signifikan terhadap efektivitas kampanye politik, dimana fiturfitur pada Facebook memperluas ruang publik untuk menjadi media promosi yang melibatkan publik lewat agenda politiknya yang dibagikan di media sosial ini. Popularitas calon anggota legislatif juga dapat terdongkrak dengan adanya pemanfaatan media sosial Facebook, dimana kandidat dapat mengunggah pesan politik sehingga mendapatkan dan mempertahankan pendukung yang membuat popularitas mereka semakin tinggi. Jika pesan yang disampaikan kandidat di Facebook dianggap menarik, maka pendukung dapat dengan mudah membagikan kepada temannya sehingga menambah popularitas dari kandidat politik ke publik.

Secara teoritis, penelitian dapat merekomendasikan teori uses and gratification serta konsep komunikasi politik menggunakan media Facebook sebagai strategi untuk meningkatkan elektabilitas, efektivitas, dan popularitas calon anggota legislatif. Secara praktis penelitian dapat menjadi pertimbangan pihak kandidat politik untuk mengoptimalkan penggunaan Facebook diiringi dengan pengemasan pesan yang menarik dan mudah dipahami sehingga tujuan politiknya tercapai. Keterbatasan dalam penelitian ini adalah tidak membandingkan penggunaan Facebook dengan media sosial lainnnya, serta tidak meneliti variabel lain sebagai mediator yang memberikan pengaruh tidak langsung terhadap elektabilitas, efektivitas, maupun popularitas. Penelitian menunjukkan besar pengaruh yang rendah, oleh karena itu perlu diteliti lagi faktor yang mempengaruhi elektabilitas, efektivitas, dan popularitas seperti citra politisi, afiliasi partai politik, dan hal-hal lain yang dapat bertindak sebagai variabel independen terhadap ketiga variabel tersebut.

\section{DAFTAR PUSTAKA}

Borah, P. (2016). Political Facebook use: Campaign strategies used in 2008 and 2012 presidential elections. Journal of Information Technology and Politics, 13(4), 326338. https://doi.org/10.1080/19331681.2016.1163519

Bryman, A. (2012). Social Research Methods. The British Journal of Psychiatry (4th Editio). Oxford: Oxfod University Press. https://doi.org/10.1192/bjp.111.479.1009-a

Dewi, R. K. (2019). Jelang Pemilu, Line dan Facebook Hadirkan Fitur untuk Kenali Kandidat. $\begin{array}{llll}\text { Retrieved January } & 19, \quad 2020, & \text { from }\end{array}$ https://nasional.kompas.com/read/2019/04/10/18595661/jelang-pemilu-linedan-facebook-hadirkan-fitur-untuk-kenali-kandidat?page=all

Griffin, E. (2012). A First Look At Communication Theory (8th editio). OH, United States: McGraw-Hill Education. 
Hong, S., \& Nadler, D. (2011). Does the early bird move the polls? The use of the social media tool "Twitter" by U.S. politicians and its impact on public opinion. ACM International Conference Proceeding Series, 182-186. https://doi.org/10.1145/2037556.2037583

Hong, S., \& Nadler, D. (2012). Which candidates do the public discuss online in an election campaign?: The use of social media by 2012 presidential candidates and its impact on candidate salience. Government Information Quarterly, 29(4), 455-461. https://doi.org/10.1016/j.giq.2012.06.004

Irawan, R. E. (2014). Popularitas politikus: antara kerja politik atau kehebatan televisi. Humaniora, 5(9), 1032-1036.

Lariscy, R. W., Tinkham, S. F., \& Sweetser, K. D. (2011). Kids these days: Examining differences in political uses and gratifications, internet political participation, political information efficacy, and cynicism on the basis of age. American Behavioral Scientist, 55(6), 749-764. https://doi.org/10.1177/0002764211398091

Lin, H. C. (2017). How political candidates' use of facebook relates to the election outcomes. International Journal of Market Research, 59(1), 77-96. https://doi.org/10.2501/IJMR-2017-004

McNair, B. (2003). An Introduction to Political Communication. New York: Routledge.

Mehrad, J., \& Tajer, P. (2016). Uses and gratification theory in connection with knowledge and information science: A proposed conceptual model. International Journal of Information Science and Management, 14(2), 1-14.

Muijs, D. (2004). Doing quantitative research in education with SPSS. British Journal of Educational Technology (Vol. 36). California: Sage Publications. https://doi.org/10.1111/j.1467-8535.2005.00465_12.x

Spierings, N., \& Jacobs, K. (2014). Getting Personal? The Impact of Social Media on Preferential Voting. Political Behavior, 36(1), 215-234. https://doi.org/10.1007/s11109-0139228-2

Strömbäck, J., \& Kiousis, S. (2014). 6 Strategic political communication in election campaigns. Political Communication, (January). https://doi.org/10.1515/9783110238174.109

Suprajang, S. E., Nirwanto, N., \& Firdianjah, A. (2017). The Influence of Social Media and Service Quality on Satisfaction and Loyalty. In International Conference "Sustainable Development Goals 2030 Challenges and Its Solutions" (Vol. 1, pp. 245-257). https://doi.org/10.1108/TQM-11-2012-0092

Taherdoost, H. (2018). Sampling Methods in Research Methodology; How to Choose a Sampling Technique for Research. SSRN Electronic Journal, (September). https://doi.org/10.2139/ssrn.3205035

The Jakarta Post. (2018). Indonesia, fourth highest number of Facebook users in the world. Retrieved January 19, 2020, from https://www.thejakartapost.com/life/2018/03/04/indonesia-fourth-highestnumber-of-facebook-users-in-the-world.html

Victor, O., Ikechukwu, U., Gerald, N., \& Chinedum, O. (2017). Effects Of The Social Media In The Marketing Of Political Candidates In Nigeria. British Journal of Marketing Studies, $5(6), 15-32$. 
Yousif, R. O., \& ALsamydai, M. J. (2012). The Impact of the Political Promotion via Facebook on Individuals' Political Orientations. International Journal of Business and Management, 7(10). https://doi.org/10.5539/ijbm.v7n10p85

Zeng, D., Chen, H., Lusch, R., \& Li, S. H. (2010). Social media analytics and intelligence. IEEE Intelligent Systems, 25(6), 13-16. https://doi.org/10.1109/MIS.2010.151

Zhang, L., \& Peng, T. Q. (2015). Breadth, depth, and speed: Diffusion of advertising messages on microblogging sites. Internet Research, 25(3), 453-470. https://doi.org/10.1108/IntR-01-2014-0021 